\title{
The Peer-to-Peer market for tourist accommodation in Latin America. Supply, Demand and Prices.
}

\author{
Beatriz Benítez-Aurioles ${ }^{1}$ \\ bbaurioles@uma.es \\ University of Málaga, Spain
}

\begin{abstract}
Purpose: Providing empirical evidence on the hosts, product and price formation of the $\mathrm{p} 2 \mathrm{p}$ market for tourist accommodation in four Latin American cities, comparing results and highlighting its main characteristics with regards to consolidated tourist destinations.

Designlmethodology/approach: Data comes from a total of 53,836 listings scraped in mid-March 2019 of the listings on the Airbnb platform for the cities of Buenos Aires (Argentina), Mexico City (Mexico), Rio de Janeiro (Brazil) and Santiago (Chile) that are among the most visited in the world. The theoretical is based on an economic hedonic price regression model; and using variables measuring host and accommodation attributes, location, booking policy, number of reviews and amenities, identifies among those what determines supply, demand and pricing.
\end{abstract}

Findings: The p2p market in Latin America has a wide margin to continue growing and to configure itself as a professional market for the rental of entire homes in the short term. There is high concentration of demand in a few accommodations. Relations between variables hint that hosts are not exploiting the full capacity to efficiently manage their accommodation prices. All this suggests that, in emerging markets, unlike in mature tourist destinations, the incorporation of specific elements, such as those related to equity and the distribution of added value, is pertinent in a global framework for the valuation of the social welfare generated by trade made through Airbnb.

Research limitationslimplications: The fact that the number of reviews has been used as a proxy is a limitation and adds a provisional character to our results and encourages the replication of our analysis with data on the effective occupation of the accommodation, to which we did not have access to in our case. Similarly, if possible, other smaller Latin American cities could be studied.

Practica/ implications: The differences detected in price formation in four Latin American cities with respect to previously analyzed consolidated destinations could suggest that, in certain regions, hosts are not taking full advantage of the potential of the market, which might be an opportunity for the proposal of programs improving the management capacity of individual owners.

Social implications: Given the inequality detected across hosts, if a policy priority is a more equalitarian distribution of income that is brought by tourist rentals to locals, a system that allocates permits according to the criteria reflected by social preferences could be tested.

Originalitylvalue: This research represents the first analysis of the peer-to-peer market for tourist accommodation that takes as a reference several Latin American cities, with theoretical and practical implications that could be extended to other emerging markets, paying special attention to the potential for the development of tourism and the distributional implications.

Keywords: Peer-to-peer market; Airbnb; Latin America; supply; demand; prices

Paper type: Research paper

\footnotetext{
${ }^{1} \mathrm{Ph} . \mathrm{D}$. in Economics and Assistant Professor of Economic Policy at the University of Malaga. MSc Economics and Finance at CEMFI. Expanded studies at London School of Economics and University College of London. One of her research areas consists of the analysis of peer-to-peer market for tourist accommodation, publishing in Current Issues in Tourism, International Journal of Contemporary Hospitality Management, Tourism Management, Tourism Economics, etc. (C)This article is published under the Creative Commons Attribution (CC BY 4.0) license. Anyone may reproduce, distribute, translate and create derivative works of this article (for both commercial and non-commercial purposes), subject to full attribution to the original publication and authors. The full terms of this license may be seen at http://creativecommons.org/licences/by/4.0/legalcode
}

Peer-to-Peer market for tourist acommodation 


\section{Introduction}

JTA

28.1

The tourism industry in Latin America is growing and contributes in the fourth place to the world GDP (Biscayart et al., 2020). Despite that, among factors that traditionally have limited the development of tourism in Latin America, from the point of view of both the source and the host, we find: economic and financial instability, structural unemployment, inflationary pressures, unequal distribution of income, uncontrolled urbanization, low levels of security, health risks, deficient air connectivity, and political uncertainty (Strizzi and Meis, 2001). This explains that tourism in the region still presents relatively modest results. Thus, for example, in 2017, the arrival of international tourists to Latin America meant $8.4 \%$ of world's total (World Tourism Organization, 2019). It has also been cautioned that economic benefits related to conventional accommodation are absorbed by a few foreign investors: international hotel chains, resorts, or even cruises would generate a flow of income that would not reach the population, besides provoking undesirable environmental impacts (Santos, 2018).

In the aforementioned context, the effects of the so-called sharing economy on tourism has aroused special interest due, among other reasons, to its impact on cities (Moreno-Gil and Coca-Stefaniak, 2020). More concretely, the academic literature on the peer-to-peer (p2p) market for tourist accommodation has reached a considerable volume that has justified various surveys to sort contributions and indicate the lines where greater research effort is needed (Dann et al., 2019; Dolnicar, 2019; Guttentag, 2019; Prayag and Ozanne, 2018). Most research has taken Europe, Canada or the United States as a reference, while others like Latin America have received minimal attention. It has been argued that there are difficulties to find quality studies in English (Netto and Trigo, 2018). Regarding the $\mathrm{p} 2 \mathrm{p}$ market for tourist accommodation, the scarcity is even more pronounced. In a recent review of Airbnb publications up to July 2018, only 1.8\% referred to Latin America (Guttentag, 2019). Moreover, the presence of Airbnb is shown to have certain beneficial effects on the economies of hosting destinations (Fang et al., 2015, Benitez-Aurioles, 2020), so it is of special interest to find answers concerning developing nations.

Given the bias that research carried out so far on the $p 2 p$ market for tourist accommodation has, with respect to the conditions under which they operate in cities of the most developed countries, it is pertinent to know whether the stylized facts that have been perceived by the empirical evidence are confirmed in other geographical locations. In this sense, the main objective of this article is to identify the basic characteristics of the tourist accommodation markets in Latin America, to check, on the one hand, if the variables that determine supply, demand and prices (mainly host and accommodation attributes, location, booking policy, number of reviews and amenities) have a different weight or influence from those described in consolidated destinations - and, particularly, in North America and Europe. On the other hand, given the special relevance of inequality problems in emerging economies and, notably, in Latin America, an approach to the role that said market plays in income distribution is intended.

Consequently, this article aims to cover two aspects that, until now, have not been specifically addressed in the literature. First, the analysis of the $\mathrm{p} 2 \mathrm{p}$ market for tourist accommodation in Latin America: we will take as reference four cities of special relevance - Buenos Aires, Mexico City, Santiago and Rio de Janeiro. From a more general point of view, the results of our analysis may suggest ideas, not only to define the limitations and opportunities for tourist development in this geographical area, but to provide information on what may be happening in other emerging tourism markets. The capitals of Mexico, Argentina, Brazil (historical capital) and Santiago are demographically relevant cases. As of 2020, the cities of Ciudad de México, Buenos Aires, Rio de Janeiro and Santiago are the 1st, 3rd, 4th and 7th largest agglomerations in Latin America, hence of the world; representing each $18.4 \%, 36.9 \%, 6.35$ and $38.7 \%$ of their countries' population (Brinkhoff, 2020). Moreover, in terms of tourism, Mexico ranked 6th globally and 1st in Latin America in terms of tourist arrivals, with 41.5 million in 2018 (SECTUR, 2019). Brazil is among the 40 most visited countries in the world according to the UNWTO, and Rio is only Brazilian city among the 100 cities ranking that receive most foreign tourists in 2016 (Euromonitor, 2016). In 2013, the market shares as tourist destinations in South America were 20.7\% for Brazil, 20.4\% in Argentina and 13\% in Chile (Cumbrera et al., 2016).

Secondly, the aim is to advance in the knowledge of the distributional implications that the emergence of the $\mathrm{p} 2 \mathrm{p}$ markets for tourist accommodation has had. Some punctual contributions can be found on this topic (Mao et al., 2018; Schor, 2017) that, anyhow, are not related to the conditions in the least consolidated destinations. Perhaps, the difficulty in accessing the data of the $\mathrm{p} 2 \mathrm{p}$ accommodation platforms - which are very reluctant to share the information - together with the absence of official statistics, can explain the lack of empirical work contributing to the knowledge of the effects of Airbnb's expansion on equity. As a consequence, it is relevant to deal with this task; although in an approximate manner, as done in this paper.

The paper is organized into the following sections. First, we make a literature review. Next, we present the methodology based on economic analysis. Consequently, following the conventional approach, discussion and results are organized differentiating those related to supply, demand, and prices. Finally, conclusions include practical theoretical and social implications, limitations, and future lines of research. 


\section{Related Literature}

The recent irruption of the $\mathrm{p} 2 \mathrm{p}$ market for tourist accommodation is significantly altering the patterns in which the tourism business had operated so far. Expressions such as sharing economy or collaborative consumption are commonly found in the literature, suggesting a difference with regards traditional economy (and more concretely, in the sphere of tourism) versus the traditional hotel market. Nonetheless, evidence has also been provided that there are motivations aside from profit-making to use Airbnb. There is an extensive range of contributions, many of which based on surveys, that testify that accommodation demand in the p2p market is explained by both economic and emotional reasons (Guttentag, 2015; Möhlmann, 2015; Tussyadiah and Pesonen, 2016). From the hosts' point of view, the importance of both types of motivations has also been made clear (Deale and Crawford, 2018; Karlsson and Dolnicar, 2016). There are, thus, both economic and noneconomic motivations to use Airbnb; both from the guests' and the hosts' behalf. However, if the emphasis to define what is understood as sharing economy shifts from participants' motivations to the mechanisms of the platform to facilitate the meeting of individual sellers and buyers, then the debate as to whether Airbnb belongs to the sharing economy or not ceases to be relevant. Given that undoubtedly Airbnb and many other Internetbased firms facilitate transactions, then the focus would shift to the study of $p 2 p$ markets, with which we would avoid semantic confusion (Belk, 2014) when we refer to the sharing economy. From this angle, sociological or psychological analyses lose interest compared to those that are purely economic. Therefore, we will use the framework provided by economic analysis in our study, and we will assume that the analysis of the p2p market for tourist accommodation does not fundamentally differ that of the traditional market - that is, in both markets, supply and demand agents interact in order to maximize their utility and profit functions. Thus, studies in recent years, such as Benítez-Aurioles (2018a), Cai et al. (2019), Chen and Xie (2017), Gibbs et al. (2018), and Wang and Nicolau (2017), have estimated, the price determinants of Airbnb listings in diverse geographic areas, using a hedonic regression model based on the economic theory of revealed preferences.

In such a context, the emergence of platforms that, through the Internet, match supply and demand of individuals, offers new opportunities for the development of local economies (Sigala and Dolnicar, 2017). Among such platforms, Airbnb, whose leadership is undisputed (Hajibaba and Dolnicar, 2017), is experiencing remarkable growth in Latin America (Zaleski, 2017) despite the problems that have traditionally limited tourism development in the region, such as those related to security (Strizzi and Meis, 2001). However, it should be noted that although users of the p2p market may prefer unsafe accommodation in a safe destination (Lau et al., 2019), nowhere - not even established destinations - can the risk assumed by tourists when they travel be fully eliminated (Benítez-Aurioles, 2019a).

It has been affirmed that in Latin American societies, exchanges in the sharing economy-in particular, in the tourism sphere - are underpinned by different foundations and structures than in western societies (Clausen and García, 2017). For instance, Buenadicha et al. (2017) remark that trust is the key to success of platforms such as Airbnb that operate in the two-sided markets (Rochet and Tirole, 2003). However, Latin America registers the lowest levels of trust in the world (Latinobarómetro, 2018): only 14\% of respondents say that they can trust most people; in the case of Brazil this percentage is of $4 \%$. Then, it is natural to believe that, therefore, reputation mechanisms established by the platforms to prevent uncertainty and problems associated to asymmetric information can play a major role in Latin America.

Meanwhile, it could be argued that access to the $\mathrm{p} 2 \mathrm{p}$ market for tourist accommodation which requires Internet connection, could be widening the gap between marginal population groups that operate in the informal economy and those that have access to information technologies. It is also said that in Latin American societies, exchanges in the sharing economy-in particular, in the tourism sphere-are underpinned by different foundations and structures than in western societies (Clausen and García, 2017). In any case, the situations in the region present a wide variety, so any generalization is risky. For example, the proportion of homes with Internet access in Argentina (81.3\%) and in Chile (87.5\%) is similar to that of developed countries, while in Brazil (60.8\%) and Mexico (50.9\%) they are appreciably smaller (ITU, 2018). Even within each country, differences can be important, given that supply and demand of digital products is greater in urban areas (BBVA Research, 2017). Latin America is the most urbanized region, where $80 \%$ of its population lives in cities, a proportion even higher than that of the most developed countries (UN Habitat, 2012). This is what in fact could propel the markets that operate through the Internet, in general, and the $\mathrm{p} 2 \mathrm{p}$ market for tourist accommodation, in particular.

Moreover, there is appreciable heterogeneity in the spatial distribution at an urban level. López-Gay et al. (2019) analyzed the cases of Mexico City and Sao Paulo and noted that, unlike for European and American cities, there is a striking contrast between the zones with bigger and smaller Airbnb presence, associated to severe socioeconomic segregation. Navarrete (2020) noted the gentrification process in San Miguel de Allende (Mexico) driven by the penetration of Airbnb rentals, detecting certain analogies with the processes experienced by cities such as London, New York, or Paris. However, he also detected growing rent gaps and the accentuation of inequalities.

Our study aims to provide an additional dimension that helps to configure a global theoretical framework on the consequences that the sharing economy is having in the tourism field. It is about knowing the characteristics that the $\mathrm{p} 2 \mathrm{p}$ accommodation market presents in destinations that have a lesser degree of development to confirm or, where appropriate, qualify the stylized facts that have been observed in more mature tourist environments. In this way, we will be able to have a more complete and less biased vision of the patterns that make up the functioning - hosts, product, price formation - of this market in the world. We do not intend, therefore, a simple description of the data that leads us to trivial statements, but rather the identification of key elements that allow us to understand the consequences of Airbnb in places where it has had a later implementation and which continue to experience rapid growth, unlike what happens in certain European cities where the phenomenon seems to have stagnated or even decreased (Adamiak, 2019).

The Latin American cities on which we have based this article are an excellent reference point to learn about what might be happening in other emerging markets located in Asia or Africa (Airbnb, 2019a), where the inequality in the distribution of benefits and the impacts caused by the expansion of Airbnb are especially acute. This is an aspect that, from a theoretical point of view, can help determine the consequences that the $\mathrm{p} 2 \mathrm{p}$ market has on social welfare in places where the objective of redistribution of income and wealth is a priority. 


\section{Methodology}

JTA

28.1

Empirical approximations to the $\mathrm{p} 2 \mathrm{p}$ market for tourist accommodation are complicated by the absence of statistical information due to the reticence of platforms to provide this data. However, some initiatives, through scraping techniques, have sorted and posted databases that can be accessed through the Internet. InsideAirbnb.com's website has become a recurrent source for researchers (Dann et al., 2019). From that source, data related to Airbnb listings in the cities of Buenos Aires (Argentina), Mexico City (Mexico), Rio de Janeiro (Brazil) and Santiago (Chile) has been compiled referred to the performed scrapings in mid-March 2019. These cities are not only among the most populous in Latin America, but also among the most visited in the world (Yasmeen, 2019).

In accordance with the adopted approach, we will perform a conventional approximation to the $\mathrm{p} 2 \mathrm{p}$ market for tourist accommodation in Latin America, sequentially studying supply, demand and prices. On the supply side, its importance will be determined in relative terms (number of listings per inhabitant), its composition (according to the type of accommodation), and the weight of the hosts that offer more than one accommodation. On the demand side, we will evaluate its growth over time, its concentration in a part of the supplied accommodation, and in those that belong to professional hosts. Finally, the analysis focuses on price formation. In this sense, a review of the literature on strategies in the hospitality sector evidences that prices are influenced by physical attributes of the hotel, quality signals (star rating, for instance) and the distance to the center of the city, to a transport hub or to some tourist attraction (the beach, for instance) (Abrate et al., 2011). As for studies on pricing in Airbnb, we have distinguished the following main categories of variables:

a) Accommodation attributes. In principle, the type of accommodation is a basic variable that influences the price insofar as, ceteris paribus, entire homes should be more expensive than private rooms; and these, in turn, than shared rooms. Besides, it is noted that as the number of bedrooms, bathrooms, or guests that can be hosted in the accommodation increases, so does price. Such attributes are associated with the size of the accommodation, and consequently, are positively related to price as one would expect.

b) Host attributes. In theory - or in the traditional sense, everyone in the p2p market should be an individual not associated to the tourism business, at least through this channel. But, in reality, there are some hosts that act as intermediaries between the owner and the guest, and are advertising several listings at once. Typically, studies refer to hosts as professional as soon as they own more than one listing. In any case, it has been shown that professional hosts are able to adapt their prices in a more efficient manner when facing demand fluctuations (Li et al., 2016). On the one hand, Airbnb awards the superhost distinctive to those that, on average, have obtained a general rating of no less than 4.8 stars; answer at least to $90 \%$ of messages within a maximum of 24 hours; get at least 10 visits per year; and only cancel bookings in exceptional circumstances (Airbnb, 2020). Anyway, reviewing the literature, we find numerous references showing that there is a positive association between accommodation prices and superhost ownership (Wang and Nicolau, 2017; Gunter, 2018).

c) Distance. For the case of hotels, results on the influence of distance are remarkably consistent: the closest the hotel is to the city center, the more expensive the room prices are. Yet, there is also evidence of the relationship being the other way round (Chen and Rothschild, 2010), non-significant (Hung et al., 2010), or overestimated, in terms of the central location premium (Lee and Jang, 2012). By contrast, as far as we are aware of, studies considering the influence of distance in Airbnb accommodation registered no exceptions: in all cases, the farthest the accommodation is from the city center, the lowest its price is (Gibbs et al., 2018; Tebuner et al., 2017; Wang and Nicolau, 2017).

d) Reviews. The number of reviews has repeatedly proven to be negatively related to price (Benítez-Aurioles, 2018a; Wang and Nicolau, 2017). Perhaps, the most elementary explanation that has been put forward is that listings with lower prices attract more guests, and therefore, get more reviews. Put differently, it is a mere expression of the law of demand. Consequently, in the absence of more specific data, the number of reviews has been used as an approximation to the demand for accommodation (Quattrone et al., 2016; Benítez-Aurioles, 2019a).

e) Booking. Airbnb offers a number of options for hosts to define based on their preferences. Thus, flexible cancellation, as opposed to stricter ones, allows a full refund if cancellation is made at least 24 hours before expected arrival time. The instant booking option allows, like in conventional accommodation, to have one's booking request instantly confirmed. There are theoretical and empirical arguments that support the thesis that owners use the more flexible booking option to increase the attractiveness of their accommodation, and hence compensate, to a certain extent, for the lack of other attributes (Benítez-Aurioles, 2018a). This would explain the inverse relationship that is frequently detected between the accommodations with flexible cancellation or instant booking, and prices.

f) Amenities. The relationship of certain amenities to prices is trivial. For instance, that the provision of air conditioned, Wi-Fi, or family friendly has a positive effect on price. Others, however, deserve some additional comment. For example, in one case, breakfast provision was negatively related to the price (Wang and Nicolau, 2017). The attempt to make the accommodation attractive by offering an additional service could be understood as a strategy by hosts to maximize their profit. As for the "smoking allowed" option, Kennedy et al. (2018) which, using Canada as a reference, evidenced that Airbnb accommodation that allows smoking can be significantly less expensive than smoke-free options in certain markets. To explain this relationship, one could think that, perhaps, the host tries to compensate the lesser quality of his/her accommodation by offering this amenity, which makes it more attractive to smoking guests.

On the aforementioned basis, and through the variables contained in Table 1, the following estimation is proposed:

$$
\begin{gathered}
\log \mathrm{P}_{\mathrm{i}}=\beta_{1} \mathrm{EH}_{\mathrm{i}}+\beta_{2} \mathrm{BD}_{\mathrm{i}}+\beta_{3} \mathrm{BT}_{\mathrm{i}}+\beta_{4} \mathrm{AM}_{\mathrm{i}}+\beta_{5} \mathrm{HL}_{\mathrm{i}}+\beta_{6} \mathrm{SH}_{\mathrm{i}}+\beta_{7} \mathrm{DT}_{\mathrm{i}}+\beta_{8} \mathrm{NR}_{\mathrm{i}}+\beta_{9} \mathrm{IB}_{\mathrm{i}}+\beta_{10} \mathrm{FC}_{\mathrm{i}}+\beta_{11} \\
\mathrm{AC}_{\mathrm{i}}+\beta_{12} \mathrm{SA}_{\mathrm{i}}+\beta_{13} \mathrm{WF}_{\mathrm{i}}+\beta_{14} \mathrm{FM}_{\mathrm{i}}+\beta_{15} \mathrm{BF}_{\mathrm{i}}+\beta_{0}
\end{gathered}
$$

being $i$ the corresponding listing. 
Table 1. Description of the variables

\begin{tabular}{|c|c|c|}
\hline Name & Abbr. & Description \\
\hline Price & $\mathrm{P}$ & $\mathrm{Nightly}$ price (in the currency of each coumtry) \\
\hline Entire home & EH & 1 if accommodation is entire home, 0 if prinate or shared room \\
\hline Bedrooms & $\mathrm{BD}$ & Number of bedrooms \\
\hline Bathrooms & $\mathrm{BT}$ & Number of bathrooms \\
\hline Accommodates & $\mathrm{AM}$ & Marimum beddable guests \\
\hline Hogt distings count & HL & Number of listings offered by the host \\
\hline Superhost & $\mathrm{sH}$ & I if onner is Superhost, 0 if not \\
\hline Distance & DT & Distance in km to the center of the city $\left({ }^{*}\right)$ \\
\hline No. reviews & $\mathrm{NR}$ & Number of received reviews \\
\hline Instant book & $\mathbb{B}$ & I if instant book ig enabled, 0 if not \\
\hline Flexible cancel. & $\mathrm{FC}$ & 1 if cancellation policy is flerible, if stricter \\
\hline Air conditionive & $\mathrm{AC}$ & 1 if air couditioming, 0 if not \\
\hline Smoking allowed & $\mathrm{SA}$ & $I$ if sumeking allouved: 0 if not \\
\hline Wi-Fi & MF & 1 if $\mathrm{Ni}-\mathrm{Fi}: 0$ if not \\
\hline Family-friendly & $\mathrm{FF}$ & $l$ if family-frienslly, 0 if not \\
\hline Brealfingt & $\mathrm{BF}$ & 1 if braalfast included, 0 if not \\
\hline
\end{tabular}

Peer-to-Peer market for

tourist

acommodation

(*) Plarra de mayo in Buenon Sires; Plaza de la fonsturucion in Merico Cits; Flaza Quinze de Nortenbra is Rio de Layerix: Plara de scous in Santiago.

The proposed semilogarithmic estimation allows to determine the percent changes in prices when a unit of the explanatory variables is altered through the coefficients $\beta_{i}$. However, in the case of dummy variables (those that only take values 0 or 1 ), the exact relationship is $\mathrm{g}=\mathrm{e}^{\beta}-1$, where $\beta$ is the coefficient associated to the dummy variable and $\mathrm{g}$ is the relative change in prices (Halvorsen and Palmquist, 1980). The estimated coefficients allow for comparison of results across cities despite prices being expressed in different currencies, since these calculations are in terms of percent changes.

\section{Results and discussion}

The presentation of results and discussion is made in three subsections: supply, demand and prices. As indicated, the data that supports our analysis comes from the scrapings carried out by InsideAirbnb.com or that defines itself as "an independent, non-commercial set of tools and data that allows you to explore how Airbnb is really being used in cities around the world" (InsideAirbnb, 2019).

\subsection{Supply}

A first approximation to the characteristics of Airbnb's accommodation in the selected cities, collected in Table 2, shows a relatively modest penetration, ranging from 2.7 listings per 1,000 inhabitants in Rio to 0.8 in Mexico. These figures are very distant from what is observed in big European cities such as Paris (8.0), London (6.3), Rome (8.8) or Barcelona (6.7) (Adamiak, 2018).

Table 2. Characteriticg of the accummadrim supply of Airbnb. Narch 2019.

\begin{tabular}{|c|c|c|c|c|}
\hline & Boenos Aires & Meico & FiD & Sancigo \\
\hline \multicolumn{5}{|l|}{ Lisings } \\
\hline Mrmber & 18,222 & 17,229 & $\exists 6,378$ & 15,790 \\
\hline (c1000 inhabirants) & 1.21 & 0.80 & 27 & 2.3 \\
\hline Entire home ("9) & 74.9 & 482 & $71 \exists$ & 55.9 \\
\hline Privale ruemen (6) & 22.3 & 598 & 264 & 41.7 \\
\hline Shared room (S6) & 28 & 20 & 24 & 2.4 \\
\hline \multicolumn{5}{|l|}{ Hosts } \\
\hline Profearional (36) & 47.0 & 48 & 41.4 & 40.3 \\
\hline Supertort ("6) & 19.6 & 28.6 & 9.6 & 11.9 \\
\hline \multicolumn{5}{|l|}{ Buabing policy } \\
\hline Flerible cancellation & 44.6 & 509 & 433 & 67.3 \\
\hline Instant booking & 49.3 & 45 & 383 & 60.8 \\
\hline
\end{tabular}


Airbnb accommodation is classified into three categories: entire homes, private rooms, and shared rooms. The percentage that private and shared rooms represent is relatively high compared to those registered in cities of the United States, Canada and Europe (InsideAirbnb, 2019).

Another common characteristic of the Latin American cities under study refers to the percentage of listings that belong to hosts that offer more than one accommodation. These percentages are lower than those detected globally, which, according to some estimates, would be close to $60 \%$ (Adamiak, 2019). Conventionally, hosts that offer more than one accommodation are referred to as "professionals".

Consequently, on the supply side, the $\mathrm{p} 2 \mathrm{p}$ market that we are considering has, in relative terms, a low level of implementation, a high share of rooms shared with the host, and a small percentage of professional providers. All of this is compatible with a market that has ample scope to continue expanding until reaching the levels detected in mature tourist destinations.

\subsection{Demand}

The analysis of demand in the $\mathrm{p} 2 \mathrm{p}$ market is hampered by the lack of data and cannot be circumvented through scraping, as it has been done for supply. Nonetheless, reliable approximations through the number of reviews received by accommodation can be obtained, to the extent that only guests that have effectively booked it can leave a review (Quattrone et al., 2016; Benítez-Aurioles, 2019b). Figure 1 shows the evolution of the number of reviews received by the listings that were active in each city in March 2019, and shows that the expansion of the market in Latin America is relatively recent, starting its exponential growth in 2014.

\section{Figure 1. Evisution of the number of listing active in March 2019}

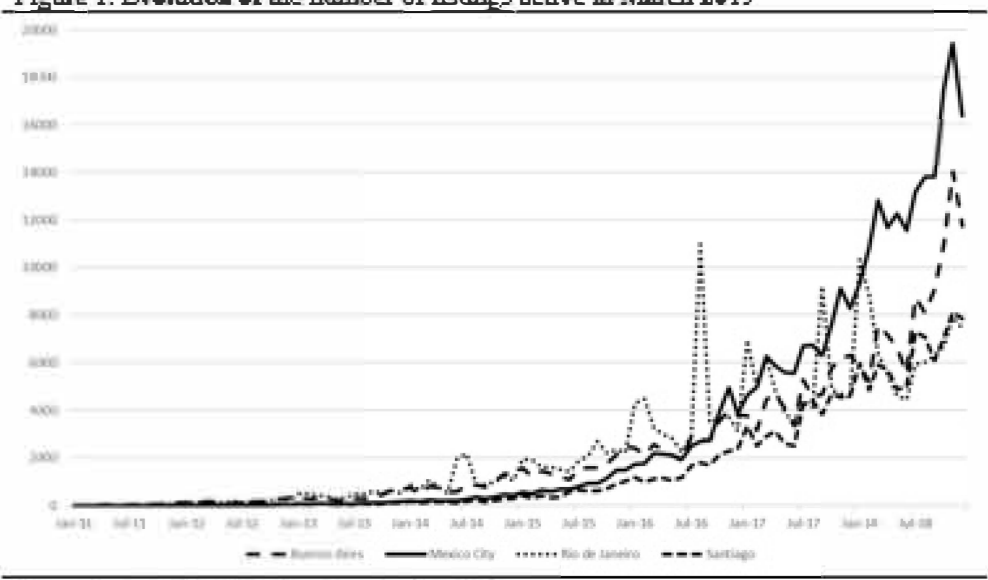

Source: Compiled from Insideaintbo (2019)

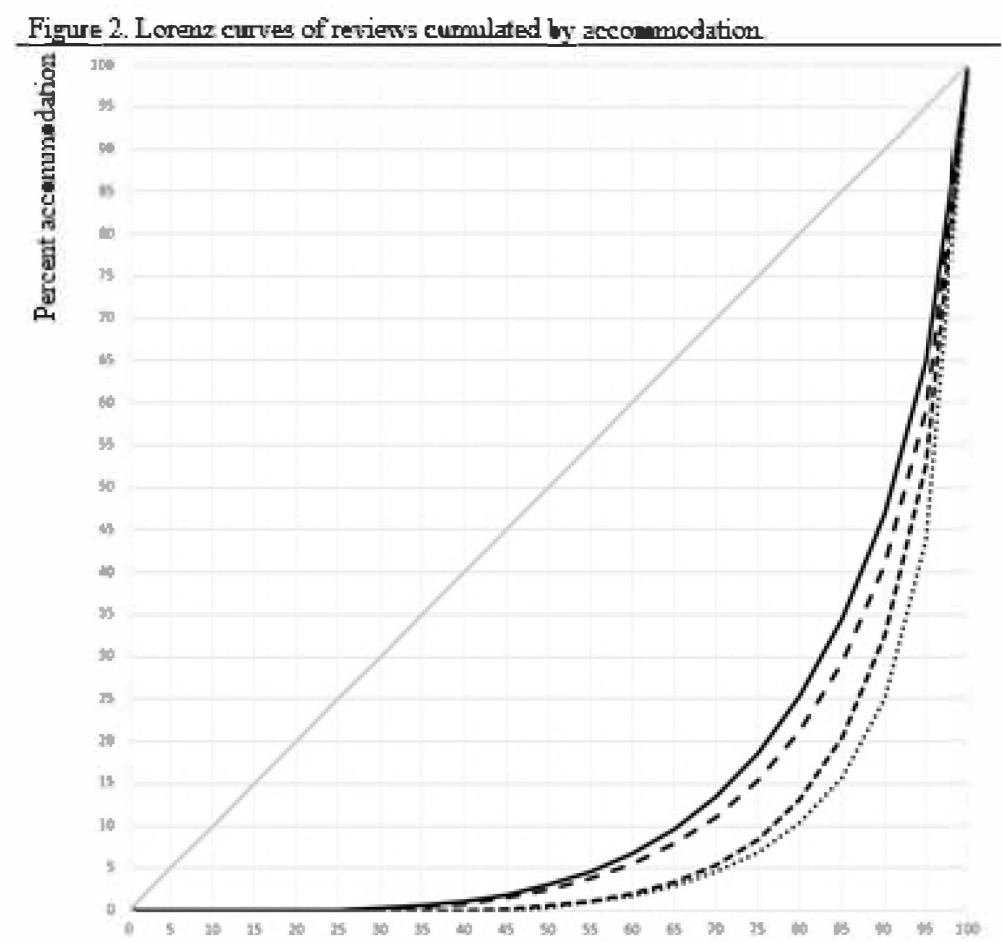

Percent revieus

- - Buenos Aires - Mescocky ....... Riodehnein

- - santibo

Source: Compiled from Insideairbmb (2019) 
The distribution of reviews among accommodation allows to qualify the data concerning supply. Figure 2 plots the Lorenz curve, relating the cumulated percentage of accommodation and of reviews. The concentration of reviews in few accommodation is particularly high in Rio (20\% of accommodation absorb $90 \%$ of reviews) and Santiago $(20 \%$ absorbs $87 \%)$. In terms of this criterion, these cities are the two most extreme cases in the world according to the data provided by Insideairbnb (2019). These figures can be connected to inequality problems that are prevalent in Latin American societies. That is to say, having market access does not guarantee demand for a part of the supply. The hypothesis that actually few people benefit from the $\mathrm{p} 2 \mathrm{p}$ market in Latin America can be made here.

As a complement to the above, only the listings with at least one review are selected, which guarantees that the accommodation has been occupied, and therefore, has been traded in the market. Under this criterion, it can be observed in Table 3 that more than $50 \%$ of listings belong to professional hosts. Moreover, there is a positive association between listings with bigger demand - corresponding to accommodation with a number of reviews higher than the median —and professional hosts.
Peer-to-Peer market for tourist

acommodation

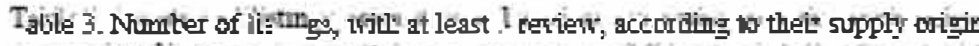

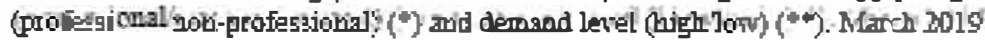

\begin{tabular}{|c|c|c|c|c|c|c|c|}
\hline \multicolumn{4}{|c|}{ Euenos flires } & \multicolumn{4}{|c|}{ Merico City } \\
\hline \multicolumn{4}{|c|}{ Numbe of listings = $129 \$ 4$} & \multirow{4}{*}{\multicolumn{4}{|c|}{ 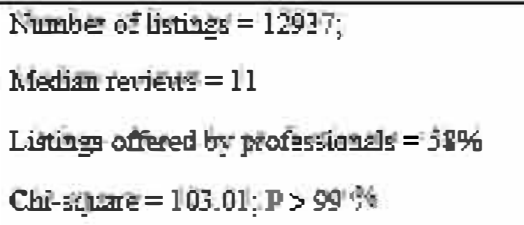 }} \\
\hline \multicolumn{4}{|c|}{ Median renetis = 7} & & & & \\
\hline \multicolumn{4}{|c|}{ 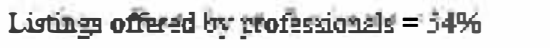 } & & & & \\
\hline \multicolumn{4}{|c|}{ Chi-stine = $16.31 ; P>090 \%$} & & & & \\
\hline & & \multicolumn{2}{|c|}{ Deniand } & & & \multicolumn{2}{|c|}{ Derrand } \\
\hline & & High & Lorx & & & High & Lot: \\
\hline \multirow{2}{*}{ supply } & Profeysiomal & 3501 & 3430 & \multirow{2}{*}{ Supply } & Profergional & 4004 & 3646 \\
\hline & Non-profegsional & 2839 & 3124 & & Non-piofersional & 2256 & 2921 \\
\hline \multicolumn{4}{|c|}{ Rio } & \multicolumn{4}{|c|}{ Snotigg } \\
\hline \multicolumn{4}{|c|}{ Number of listings = 19123} & \multirow{4}{*}{\multicolumn{4}{|c|}{ 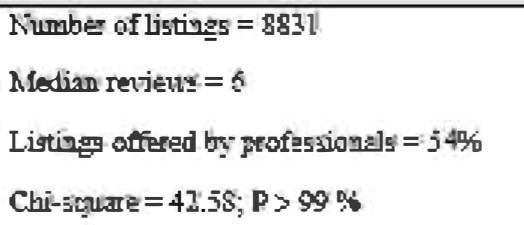 }} \\
\hline Median & Ieviens $=4$ & & & & & & \\
\hline Listing & offered by jrofesri & 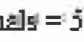 & & & & & \\
\hline \multicolumn{4}{|c|}{ Chi-sclume $=46.58 ;$ p $>99 \%$} & & & & \\
\hline & & \multicolumn{2}{|c|}{ Demand } & & & \multicolumn{2}{|c|}{ Derranat } \\
\hline & & High & Low & & & High & Low \\
\hline \multirow{2}{*}{ supply } & Profezsiongl & 4665 & 5172 & \multirow{2}{*}{ Supply } & Profexaional & 2437 & 2254 \\
\hline & Non-profersional & 3946 & 5340 & & Non-profengúüJal & 1866 & 2274 \\
\hline
\end{tabular}

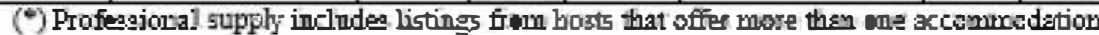
while non-professional sifoly Jefes to liatiog of host that owly offer ane accommodation.

(*) Ljstings with high demand are those that lare receñad a mmiter of rewiews abone the median, thile those uith low demand refer to thoge that hace recejied s wumber of reviens: zquai or belowit the median

$\mathrm{P}$ : probability of as 3ociatiou between both variables.

Sorrce: Compiled from Inajdeairbnb (3019)

\subsection{Prices}

The estimation of the model proposed in [1] has been made among listings which had at least 1 review, to ensure that they have been traded in the market. Results are collected in Table 4. 
Table 4. OLS jagreagion on log price. Recilts.

JTA

28.1

\begin{tabular}{|c|c|c|c|c|}
\hline Price & BuE 05 सIR्? & Mlexlco City & KW0 & Sartilagb \\
\hline Ertire home & $0.001 \% क ् म$ & $0.13 y^{2}$ & $0.510^{+\infty}$ & $0.617^{+25}$ \\
\hline Bedrooma & $0.10 \$++$ & 0.00692 & $0.222^{+* *}$ & $0.0728+4 *$ \\
\hline Bathroom; & $0.146^{++*}$ & $0.0765^{+4 t}$ & $0.169^{+* *}$ & $0.0354^{+4+}$ \\
\hline Accoumoudates & $0.10 \Sigma^{+++}$ & $0.0830^{+* *}$ & $0.0187^{*+*}$ & $0.0875+4$ \\
\hline Host listings count & $0.011^{4+*}$ & $0.00895^{++*}$ & $-0.000379 *$ & $0.000372 *$ \\
\hline Superthost & $0.0653+4+$ & $0.0465^{++*}$ & $-0.125^{5+4}$ & -0.0168 \\
\hline Distance & $-0.0076 \mathrm{~s}^{+4}+$ & $-0.00555+4$ & $0.00324 * * *$ & $0.03 .28+4$ \\
\hline No. Jeriens & $-0.000387^{*}$ & $-0.00116^{+* *}$ & $-0.003 .21^{++*}$ & $-0.001120++*$ \\
\hline 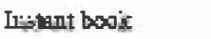 & $-0.0522+4+$ & $-0.0598+4$ & $-0.0795+4 *$ & $-4.0274^{*}$ \\
\hline Flexible cariel. & $-0.035 \mathrm{~g}^{*}$ & $-0.0560^{*+5}$ & $-0.02 T^{+\infty}$ & -4.00165 \\
\hline fir conditianing & $0.303^{+\infty+}$ & $0.334^{*+*}$ & $0.35 I^{2+*+}$ & $0.345^{+4 *}$ \\
\hline Sholing alloued & $-0.132++*$ & $-0.0867^{++4}$ & $-0.0431+\infty$ & $-0.0641^{+* *}$ \\
\hline Thi-Fi & $0.0820^{*}$ & 0.038 & $0.0495^{+*}$ & $0.0839^{++*}$ \\
\hline Family-fiendily & $0.11^{++\infty}$ & $0.101^{++\infty}$ & $0.0716+* 4$ & $0.118^{+* *}$ \\
\hline Breakizist & 0.0742 & $0.228+4$ & $0.0 \$ 34^{++4}$ & -0.0134 \\
\hline$\varepsilon \omega$ & $5.914+4$ & $5812+4$ & $4.195+4$ & $9.015^{++*}$ \\
\hline N & 12,95 & 12,925 & 10,094 & $8,8,2$ \\
\hline 36]. R-5q & 0.481 & 0.534 & 0.451 & 0.545 \\
\hline
\end{tabular}

As expected, entire homes and accommodation with more bedrooms, bathrooms and accommodates have higher prices. Regarding booking policy, in all cases, the instant booking option and flexible cancellation are negatively related to price, which is compatible with hosts' strategy of increasing the accommodation's attractiveness by combining low prices with more appealing booking policies (Benítez-Aurioles, 2018a). Similarly, accommodation in which smoking is allowed has lower prices. The rest of amenities with statistically significant parameters (air conditioning, Wi-Fi, family-friendly, or breakfast) have the expected positive signs.

Conversely, some characteristics found in the cities under study starkly differ from previous analyses. For example, to stimulate productivity among hosts, Airbnb distinguishes those who meet a series of objectives with the Superhost label (Airbnb 2020). It could be assumed that the efforts made by the owners to obtain the Superhost status would have to be compensated by increased profitability of their listings, since they would be more demanded by potential guests who would be willing to pay higher prices (Liang et al. 2017). In fact, previous available studies have regularly detected a direct relationship between the Superhost tag and the price of accommodation (Benítez-Aurioles, 2018a; Wang and Nicolau, 2017). This does not happen in the Latin American cities analyzed. It seems, therefore, that Superhosts are not taking advantage of their reputation in the market to raise the prices of their accommodation.

Likewise, the fact that, in Rio and Santiago, accommodation further away from the historical center is more expensive deviates from previous results from both the theoretical and empirical points of view (BenítezAurioles, 2018b). Here arises another characteristic as distance to the urban center does not generally determine the price of accommodation in the $\mathrm{p} 2 \mathrm{p}$ market in the Latin American cities under study.

The feature pointed out reinforce the assumption of price management techniques deviating from the usual patterns detected in other cities, which may be a consequence — at least in part — of the lack of expertise of hosts in setting prices efficiently in order to maximize their profit.

\section{Concluding remarks}

Data suggests that the $\mathrm{p} 2 \mathrm{p}$ market for tourist accommodation has had a recent development in Latin America. Since its takeoff in some cities in 2014, it has experienced exponential growth. In spite of all this, its implantation is far from the levels reached in Europe or the United States and there remains ample room for it to continue growing and configuring itself as a professional market for the short-term rental of entire homes, as it is happening globally.

A notable finding is the strong concentration of demand in few accommodations, together with the association between the most demanded accommodation and professional hosts. Although the available statistical information does not allow us to definitively confirm the impact that the $p 2 p$ market is having on income inequality in Latin America, it does encourage reflection and the formulation of a certain conjecture. In this sense, the data are compatible with a high inequality in the distribution of income generated by the $\mathrm{p} 2 \mathrm{p}$ market. This is a non-trivial finding and can serve as the basis for regulation in the sector that would distribute the benefit among the most disadvantaged.

Finally, regarding prices, even if accommodation attributes and amenities provided have the same relationships observed in previous analyses, differentiated behaviors have been detected that may be related, not only to the specific characteristics of urban design in cities, but also to less efficient price management by homeowners. First, a higher number of bedrooms is not associated to more price in Mexico City, while in Benítez-Aurioles (2018b) this variable was found positively associated to it in 44 cities from Europe, North America and Australia. Secondly, in Wang and Nicolau (2017), who studied 33 cities also from Europe, North America and Australia, distance was negatively associated to price. In our study, however, accommodation nearer the city center are not more expensive in Rio and Santiago. In this same study, it was also found that Superhosts charge a positive price 
premium; while in Rio, Superhosts do not charge signif icantly more for their accommodation. Hosts' listing count is also positively associated to price per listing in those locations, but again, this is not true in Rio. This might hint that in some of these Latin American cities, hosts are not taking advantage of having more space, being closer to the urban center, being more prof essional or experienced in the platf orm to charge higher prices. Of course, this could be simply due to pref erences; but in any case, it dif $f$ ers f rom the norm in other cities.

The theoretical implications of the study performed confirm the ability of the tools of economic analysis to understand the functioning of the $\mathrm{p} 2 \mathrm{p}$ market for tourist accommodation. The theoretical framework adopted and its methodological implementation enables the discovery of both the generalities and the characteristics of the different markets. Precisely, this contribution is a key finding that can redirect the discussion according to the conditions of each specific environment (Qiu et al., 2019). In emerging tourist markets, it is pertinent to incorporate the uneven distribution of added value generated by the $2 \mathrm{p}$ market to design a complete theoretical framework that assesses its impact on social welfare. Consequently, this encourages theoretical discussion on efficiency versus equity in the context of the $\mathrm{p} 2 \mathrm{p}$ market for tourist accommodation. This approach suggests opening a differentiated theoretical debate according to the degree of maturity of the markets. The preponderance of research on the $\mathrm{p} 2 \mathrm{p}$ market with data from European or North American cities has focused interest on the efficiency of the operation of the market; or on the effects it causes in the established tourism industry, in the market for the rental and sale of housing, or the welfare of residents in the destinations. On the other hand, the analysis that we have carried out for Latin America has theoretical implications as it highlights the distributional implications of the expansion of the $\mathrm{p} 2 \mathrm{p}$ market for tourist accommodation in emerging markets.

Among the practical implications, the contributed empirical evidence nuances the idea of the $p 2 p$ market as a tool for the reduction of inequalities. Chiefly, the concentration of demand in a few accommodations that are mainly managed by professional hosts has been demonstrated. Thus, the leeway for achieving a more balanced rent distribution in Latin America through the promotion of the $\mathrm{p} 2 \mathrm{p}$ market for tourist accommodation narrows. At the same time, this reality provides clues for the regulation of this market in function of the objectives pursued by the policymakers. Therefore, if the priority is a more equalitarian distribution of income that is brought by the $\mathrm{p} 2 \mathrm{p}$ market to local hosts, a system that allocates permits according to the criteria reflected by social preferences could be tested. On the other hand, at a more concrete level, the differences detected in price formation with respect to consolidated destinations suggest that, in certain regions, hosts are not taking full advantage of the potential of the market, which might be an opportunity for the proposal of programs improving the management capacity of individual owners.

Finally, the limitations of this work are simultaneously opportunities for future lines of research. The fact that the number of reviews has been used as a proxy adds a provisional character to our results and encourages the replication of our analysis with data on the effective occupation of the accommodation, to which we did not have access to in our case. The economic focus of this paper also means a limitation that may encourage research on the singularities of trades in the $\mathrm{p} 2 \mathrm{p}$ market for tourist accommodation in Latin America from other areas of social sciences. Analyzing the configuration of the $\mathrm{p} 2 \mathrm{p}$ market in emerging destinations unearths realities and problems that are different from those in consolidated destinations, where priorities also change. A line of research that explores how the benefits and costs of the expansion that this market is experiencing among the population are distributed will help to design mechanisms that mitigate the unequal distribution of income. The results of this research suggest that this effort is necessary, particularly in places where few are able to take advantage of offering their home to tourists.

\section{References}

Abrate, G., Capriello, A., and Fraquelli, G. (2011), "When quality signals talk: Evidence from the Turin hotel industry", Tourism Management, Vol. 32 No. 4, pp. 912-921.

Adamiak, C. (2018), "Mapping Airbnb supply in European cities", Annals of Tourism Research, Vol. 71(C), pp. 67-71.

Adamiak, C. (2019), "Current state and development of Airbnb accommodation offer in 167 countries", Current Issues in Tourism, pp. 1-19, https://doi.org/10.1080/13683500.2019.1696758

Airbnb (2019), "Emerging Markets Powering Airbnb's Global Growth", available at: https://news.airbnb.com/wpcontent/uploads/sites/4/2019/02/Final_-Emerging-Markets-Powering-Airbnbs-Global-Growth-.pdf

Airbnb (2020), "How do I become a Superhost?", available at: https://www.airbnb.com/help/article/829/how-do-i-become-asuperhost

BBVA Research (2017), "Urbanización en América Latina", available at: https://www.bbvaresearch.com/wpcontent/uploads/2017/08/Urbanizacion-en-America-Latina-BBVA-.pdf

Belk, R. (2014), "Sharing versus pseudo-sharing in Web 2.0", The Anthropologist, Vol. 18 No. 1, pp. 7-23.

Benítez-Aurioles, B. (2018a), "Why are flexible booking policies priced negatively?", Tourism Management, Vol. 67, pp. 312-325.

Benítez-Aurioles, B. (2018b), "The role of distance in the peer-to-peer market for tourist accommodation", Tourism Economics, Vol. 24 No. 3, pp. 237-250.

Benítez-Aurioles, B. (2019a), "Barcelona's peer-to-peer tourist accommodation market in turbulent times: Terrorism and political uncertainty", International Journal of Contemporary Hospitality Management, Vol. 31 No.12, pp. 4419-4437.

Benítez-Aurioles, B. (2019b), "Is Airbnb bad for hotels?", https://doi.org/10.1080/13683500.2019.1646226

Benítez-Aurioles, B. (2020), "Impacts of the peer-to-peer market on tourist accommodation on the Balearic Islands of Mallorca and Menorca", $\quad$ Island Studies Journal, available https://www.islandstudies.ca/sites/default/files/ISJBen\%C3\%ADtezAuriolesTourismAccomodationBalearics.pdf

Biscayart, C., Angeleri, P., Lloveras, S., Chaves, T., Schlagenhauf, P. and Rodríguez-Morales, A. J. (2020). "The next big threat to global health? 2019 novel coronavirus (2019-nCoV): What advice can we give to travellers? - Interim recommendations January 2020, from the Latin-American society for Travel Medicine (SLAMVI)", Travel medicine and infectious disease, Vol. 33, pp. 101567, https://doi.org/10.1016/j.tmaid.2020.101567

Brinkhoff, T. (2020), "Major agglomerations of the world", available at: https://www.citypopulation.de

Bristow, R., Yang, W. and Lu, M. (2011), "Sustainable medical tourism in Costa Rica", Tourism Review, Vol. 66 No. 1/2, pp. 107117.

Buenadicha, C., Cañigueral, A. and De León, I.L. (2017), "Retos y posibilidades de la economía colaborativa en América Latina y el Caribe", Inter-American Development Bank, No. IDB-DP-518. 
Buhalis, D., Andreu, L. and Gnoth, J. (2020), "The dark side of the sharing economy: Balancing value co-creation and value co-destruction", Psychology and Marketing, https://doi.org/10.1002/mar.21344

Cai, Y., Zhou, Y. and Scott, N. (2019), "Price determinants of Airbnb listings: evidence from Hong Kong", Tourism Analysis, Vol.

Chen, C., and Rothschild, R. (2010), "An application of hedonic pricing analysis to the case of hotel rooms in Taipei", Tourism Economics, Vol. 16 No. 3, pp. 685-694.

Chen, Y. and Xie, K.L. (2017), "Consumer valuation of Airbnb listings: A hedonic pricing approach", International Journal of Contemporary Hospitality Management, Vol. 29 No. 9, pp. 2405-2424.

Clausen, H.B. and García, M.A.V. (2017), "Collaborative Economy in Tourism in Latin America: The case of Argentina, Colombia, Chile and Mexico", in Dredge, D and Gyimóthy (Eds), Collaborative Economy and Tourism, Springer, Cham, pp. 271-284.

Cumbrera, M. G., de León, C. A. F. and Braçe, O. (2016), "A comparison of tourism industry in emerging powers (Argentina and Brazil): from rivalry to interdependence", Cuadernos de Turismo, No. 38, pp. 537.

Dann, D., Teubner, T. and Weinhardt, C. (2019), "Poster child and guinea pig-insights from a structured literature review on Airbnb", International Journal of Contemporary Hospitality Management, Vol. 31 No. 1, pp. 427-473.

Deale, C.S. and Crawford, A. (2018), "Providers' perceptions of the online community marketplace for lodging accommodations", Tourism and Hospitality Research, Vol. 18 No.4, pp. 470-477.

Dolnicar, S. (2019), "A review of research into paid online peer-to-peer accommodation: Launching the Annals of Tourism Research curated collection on peer-to-peer accommodation", Annals of Tourism Research, Vol. 75, pp. 248-264.

Dolnicar, S. and Zare, S. (2020), "Coronavirus and Airbnb-disrupting the disruptor", available at: https://doi.org/10.1016/j.annals.2020.102961

Euromonitor (2016), "Top 100 City Destinations Ranking", available at: https://blog.euromonitor.com/top-100-city-destinationsranking-2016

Fang, B., Ye, Q., and Law, R. (2015), "Effect of sharing economy on tourism industry employment". Population, Vol. 1, pp. 0-6321.

Gibbs, C., Guttentag, D., Gretzel, U., Morton, J. and Goodwill, A. (2018), "Pricing in the sharing economy: A hedonic pricing model applied to Airbnb listings", Journal of Travel \& Tourism Marketing, Vol. 35 No. 1, pp. 46-56.

Gunter, U. (2018), "What makes an Airbnb host a superhost? Empirical evidence from San Francisco and the Bay Area", Tourism Management, Vol. 66, pp. 26-37.

Guttentag, D. (2015), "Airbnb: disruptive innovation and the rise of an informal tourism accommodation sector", Current issues in Tourism, Vol.18 No. 12, pp. 1192-1217.

Guttentag, D. (2019), "Progress on Airbnb: a literature review", Journal of Hospitality and Tourism Technology, Vol.10 No.3 pp. 233-263.

Hajibaba, H. and Dolnicar, S. (2017), "Airbnb and its Competitors", in Dolnicar, S. (Ed), Peer-to-Peer Accommodation Networks: Pushing the boundaries, Goodfellow Publishers, Oxford, pp. 63-76.

Halvorsen, R. and Palmquist, R. (1980), "The interpretation of dummy variables in semilogarithmic equations", The American Economic Review, Vol. 70 No. 3, 474-475.

Hung, W-T., Shang, J-K. and Wang, F.-C. (2010), "Pricing determinants in the hotel industry: quantile regression analysis", International Journal of Hospitality Management, Vol. 29 No. 3, pp. 378-384.

InsideAirbnb, (2019), "About Inside Airbnb", available at: http://insideairbnb.com/about.html

ITU (2018), Measuring the Information Society Report, International Telecommunication Union, Geneva.

Kandampully, J. and Solnet, D. (2019), "Competitive advantage through service in hospitality and tourism: a perspective article", Tourism Review, https://doi.org/10.1108/TR-05-2019-0175

Karlsson, L., Kemperman, A. and Dolnicar, S. (2017), "May I sleep in your bed? Getting permission to book", Annals of Tourism Research, Vol. 62, pp. 1-12.

Kennedy, R., Douglas, O., Stehouwer, L. and Dawson, J. (2018), "The availability of smoking-permitted accommodations from Airbnb in 12 Canadian cities", Tobacco Control, Vol. 27 No. 1, pp. 112-116.

Lau, C.K.H., Chui, R.C.F., Lin, P.M.C, and Chan, R.T.M. (2019), "The value of P2PA to travelers: Evidence from the Hong Kong market", International Journal of Tourism Research, Vol. 21, pp. 839-854.

Lee, S.K. and Jang, S. (2011), "Room rates of U.S. airport hotels: examining the dual effects of proximities", Journal of Travel Research, Vol. 50 No. 2, pp. 186-197.

Li, J., Moreno, A., and Zhang, D. J. (2019), "Agent Pricing in the Sharing Economy: Evidence from Airbnb", in Hu, M. (Ed.), Sharing Economy, Springer, Cham, pp. 485-503.

Liang, S., Schuckert, M., Law, R. and Chen, C-C. (2017), "Be a 'Superhost': The importance of badge systems for peer-to-peer rental accommodations", Tourism Management, Vol. 60, pp. 454-465.

López-Gay, A., de Oca, Á. M.M., Sales-Favà, J., and da Cunha, J.M.P. (2019), "Apartamentos turísticos, ciudad y población en América Latina", Revista Latinoamericana de Población, Vol. 13 No. 25, pp. 5-35.

Mao, Y., Tian, X. and Ye, K. (2018), "The Real Effects of Sharing Economy: Evidence from Airbnb", Kelley School of Business Research Paper No. 18-15.

Möhlmann, M. (2015), "Collaborative consumption: determinants of satisfaction and the likelihood of using a sharing economy option again", Journal of Consumer Behaviour, Vol. 14 No. 3, pp. 193-207. 
Navarrete, D. (2020), "Foreigners as gentrifiers and tourists in a Mexican historic district", Urban Studies, https://doi.org/10.1177/0042098019896532

Netto, A. and Trigo G.G. (Eds) (2018), Tourism in Latin America, Springer, Basel.

Prayag, G. and Ozanne, L.K. (2018), "A systematic review of peer-to-peer (P2P) accommodation sharing research from 2010 to 2016: progress and prospects from the multi-level perspective", Joumal of Hospitality Marketing \& Management, Vol. 27 No. 6, pp. 649-678.

Qiu, D., Lin, P., Feng, S., Peng, K., and Fan, X. (2019). The future of Airbnb in China: industry perspective from hospitality leaders. Tourism Review. http://dx.doi.org/10.1108/TR-02-2019-0064.

Quattrone, G., Proserpio, D., Quercia, D., Capra, L. and Musolesi, M. (2016), "Who benefits from the sharing economy of Airbnb?", Proceedings of the 25th international conference on world wide web, pp. 819-836.

Rochet, J. C. and Tirole, J. (2003), "Platform competition in two-sided markets", Joumal of the European Economic Association, Vol. 1 No. 4, pp. 990-1029.

Schor, J.B. (2017), "Does the sharing economy increase inequality within the eighty percent?: findings from a qualitative study of platform providers", Cambridge Joumal of Regions, Economy and Society, Vol. 10 No. 2, pp. 263-279. SECTUR (2019), $\quad$ "Estrategia $\quad$ Nacional
https://sistemasdegestionambiental.files.wordpress.com/2019/03/estrategia-nacional-de-turismo-2019-2024-pdf.pdf

Sigala, M. and Dolnicar, S. (2017), "Entrepreneurship Opportunities", in Dolnicar, S. (Ed), Peer-to-Peer Accommodation Networks: Pushing the boundaries, Goodfellow Publishers, Oxford, pp. 77-86.

Sthapit, E. and Björk, P. (2019), "Sources of value co-destruction: Uber customer perspectives", Tourism Review, Vol. 74 No. 4, pp. 780-794.

Sthapit, E., Del Chiappa, G., Coudounaris, D. and Bjork, P. (2019), "Determinants of the continuance intention of Airbnb users: consumption values, co-creation, information overload and satisfaction", Tourism Review, https://doi.org/10.1108/TR-03-2019-0111

Strizzi, N. and Meis, S. (2001), "Challenges facing tourism markets in Latin America and the Caribbean region in the new millennium", Joumal of travel research, Vol. 40 No. 2, pp. 183-192.

Tanana, A., Rodriguez, C. and Gil, V. (2019), "Strategic tourism management to address natural hazards in coastal areas: lessons from Buenos Aires, Argentina", Tourism Review, Vol. 74 No. 3, pp. 503-516.

Teubner, T., Hawlitschek, F. and Dann, D. (2017), "Price Determinants on Airbnb: How Reputation Pays Off in the Sharing Economy", Joumal of Self-Governance \& Management, Vol. 5 No. 4, pp. 53-80.

Tussyadiah, I. P. and Pesonen, J. (2016), "Impacts of peer-to-peer accommodation use on travel patterns", Joumal of Travel Research, Vol.55 No. 8, pp. 1022-1040.

UN Habitat (2012), State of Latin America and Caribbean cities 2012. Towards a new urban transition, UN Habitat, Nairobi.

Valente, J.F., Dredge, D. and Lohmann, G. (2014), "Leadership capacity in two Brazilian regional tourism organisations", Tourism Review, Vol. 69 No. 1, pp. 10-24.

Wang, D. and Nicolau, J.L. (2017), "Price determinants of sharing economy based accommodation rental: A study of listings from 33 cities on Airbnb.com", International Joumal of Hospitality Management, Vol. 62, pp. 120-131.

World Tourism Organization (2019), Yearbook of Tourism Statistics, Data 2013 - 2017, 2019 Edition, UNWTO, Madrid.

Yasmeen, R. (2019), Top 100 City Destinations, Euromonitor International.

Zaleski, O. (2017), "Airbnb looks to Latin America, now its fastest-growing market. Bloomberg", available at: https://www.bloomberg.com/news/articles/2017-05-12/airbnb-looks-to-latin-america-now-its-fastest-growing-market. 